\title{
The Anglophone Crisis in Cameroon: A Geopolitical Analysis
}

\author{
Ekah Robert Ekah, \\ Department of 'Cultural Diversity, Peace and International Cooperation' \\ at the International Relations Institute of Cameroon (IRIC)
}

Doi:10.19044/esj.2019.v15n35p141 URL:http://dx.doi.org/10.19044/esj.2019.v15n35p141

\begin{abstract}
Anglophone Cameroon is the present-day North West and South West (English Speaking) regions of Cameroon herein referred to as No-So. These regions of Cameroon have been restive since 2016 in what is popularly referred to as the Anglophone crisis. The crisis has been transformed to a separatist movement, with some Anglophones clamoring for an independent No-So, re-baptized as "Ambazonia". The purpose of the study is to illuminate the geopolitical perspective of the conflict which has been evaded by many scholars. Most scholarly write-ups have rather focused on the causes, course, consequences and international interventions in the crisis, with little attention to the geopolitical undertones. In terms of methodology, the paper makes use of qualitative data analysis. Unlike previous research works that link the unfolding of the crisis to Anglophone marginalization, historical and cultural difference, the findings from this paper reveals that the strategic location of No-So, the presence of resources, demographic considerations and other geopolitical parameters are proving to be responsible for the heightening of the Anglophone crisis in Cameroon and in favour of the quest for an independent Ambazonia. This article however upholds that the No-So is still part of Cameroon's territorial space, considering the fact that Ambazonia is not internationally recognized as a sovereign state.
\end{abstract}

Keywords: Geopolitics, Territoriality, Anglophone Crisis, Ambazonia, The Republic Of Cameroon, Separatists/Secessionists

\section{Introduction}

This article seeks to elucidate on the geopolitical perspective on the Anglophone crisis in Cameroon. It is therefore important to have an understanding of the word geopolitics and other related terms. The term "geopolitics" was coined by a Swedish political scientist- Rudolf Kjellen at the beginning of the 20th century. He defined geopolitics as 'the theory of the 
state as a geographical organism or phenomenon in space' (Cahnman, 1943: 57). Dijkink (1996) defined it is a scientific explanation of the power and security policy of states on the basis of geographical position and/or natural resources. According to Toal (cited in Efferink, 2009), geopolitics can also be regarded as a discourse about world politics, with a particular emphasis on state competition and the geographical dimensions of power. Meanwhile, Dodds (2007) upholds that geopolitics is all about the visualization of a map, about placing one's feet squarely in history and geography, while keeping one's eyes upon a speculative future. A geopolitical analysis can also be assessed as 'an intellectual tradition, as an expression of state interest, and finally as an expression of identity politics' (Guzzini, 2010: 14). 'Geopolitics deals with concepts such as power, politics, and policy, and space, place, and territory, and embraces an innumerable multitude of interactions within these various fields' (Jones, Jones \& Woods, 2004: 170). The Inter-American Wiki gives a simpler definition of geopolitics; as, 'the struggle over hegemony in places and spaces' (Mirko \& Wehrmann, 2015).

Based on the above definitions of geopolitics, a strong correlation can be seen between geography and history. Thus, geopolitics can equally be considered to be 'a combination of history (political processes) and geography, competing authorities striving to exercise power, occupy, and administer space' (Toal, 1996: 2). The history of Cameroon from 1972 to contemporary times has been characterized by what is generally referred to as "the Anglophone problem" or "the Anglophone crisis", which heightened after 2016. In a typical geopolitical expression, the crisis is marked by territorial contestation (that is; between the separatists and the government over No-So), a phenomenon otherwise known in geopolitical studies as "territoriality". 'Territoriality is derived from the word "territory', which denotes a demarcated geographic area governed and controlled by a political institution' (Gottmann, 1973: 5, 26).According to Storey (2017), territoriality can be defined as the process whereby individuals or groups lay claim over a particular territory, it reflects a way in which space is imagined and how it can serve useful political functions. Territorial thinking is the production of territories, and the employment of territorial strategies is bound up with maintaining power or resisting the imposition of power by the dominant group (Storey 2017). This article shall focus on No-So as the contested territorial space, with the separatists striving to create an independent state called "Ambazonia". Besides the historical perspective, this drive is equally triggered by the presence of natural resources, its strategic geographical location, a reasonable population size, all of which can guarantee the status and survival of an independent nation. Meanwhile, the Cameroon government, on the other hand, remains resolute in defending the territorial integrity of the nation. 
The quest for a separate state (Ambazonia) by Anglophone Cameroonian separatists has evolved over time. Although there are substantial publications on this subject especially by Sociologists, anthropologists, historians, political scientists, lawyers and journalists, (Lunn \& Brooke, 2019; Lohkoko, 2013; Ngoh, 2019; Chereji \& Lohkoko, 2012; Fonchingong, 2011; Konings \& Nyamnjoh, 1997), most of these studies centered on the causes, manifestation and impact of the Anglophone Problem. This study is a paradigm shift from the existing abundant literature, as it props into illuminating the geopolitical undertones of the crisis. Within this perspective, investigating the ways in which the presence of natural resources, the geography and demography of No-So serves as key motivating factors to the Anglophone separatists shall be at the center of analysis. Historical memories, as well as some aspects of foreign interventions shall equally be analyzed from the geopolitical prism. It is however important to have a glimpse of the origin of the transformation of No-So into a contested territorial space as referred to by the separatists as Ambazonia.

\section{The Origin Of "Ambazonia" As A Territorial Construct}

'Etymologically, the term 'Ambazonia' is derived from the word 'Ambozes', the local name for the Ambas Bay area at the mouth of the Wouri river' (Ngoh, 2004: 6). In 1858, the Ambas Bay was settled by the English Baptist Missionaries led by Alfred Saker. The territory was renamed by the missionaries as "Victoria", which is present day "Limbe", in the South West Region of Cameroon (Burnley, 2016). The name Ambazonia was first expressed as a territorial construct in 1985 by the eminent Anglophone lawyer and first president of the Cameroon Bar Association-Fon Gorji-Dinka (Konings \& Nyamnjoh, 1997), after the Paul Biya's (current president of Cameroon) government changed the name of the country from the "United Republic of Cameroon" back to the pre-reunification name of the French Cameroon; that is, "La Republique du Cameroun" (The Republic of Cameroon) as the country is presently known. In the view of some, particularly in the English section of Cameroon, this meant the dissolution of the 1961 union between the English and French sections of Cameroon. As a result, Fon Dinka called for the Southern Cameroons (No-So) to become independent and to be re-baptized as the "Republic of Ambazonia" (Konings \& Nyamnjoh, 1997).

The name Ambazonia was declared to represent a timely intervention of the people of Southern Cameroons to return the statehood of the former British Southern Cameroons territory (Ambazonia, in Wikipedia, 2019). Also, the appellation Ambazonia was used to inject a sense of distinctive sovereign identity. Since 1985, several emancipationist entities and organizations have emerged (such as the Southern Cameroons National Council (NCNC), The 
Ambazonian Interim Government (IG), The Ambazonian Governing Council (AGovC), etc), advocating for the "restoration of independence" of this territory. It is reported that in 1992, Fon Gorji-Dinka, on behalf of the "Republic of Ambazonia" sued the Republic of Cameroon and President Paul Biya on the main charge of the Republic of Cameroon's illegal and forcible occupation since the 1984 dissolution of the United Republic of Cameroon (Konings \& Nyamnjoh, 1997).

With the creation of the Southern Cameroons National councils (S.C.N.C) in 1995, it secured Southern Cameroons (Ambazonia) a place in the "Unrepresented People Organization" (U.N.P.O) in a bid to seek international recognition. Also, 'since 1995, several Anglophone delegations have been sent to the United Nations' (Lohkoko, 2013: 29), but as reported by Konings \& Nyamnjoh (1997), such efforts to the UNO went in vain. Meanwhile, in 1999, the SCNC faction led by then Justice Ebong Alobwede took hostage of the Cameroon Radio and Television (CRTV) in Buea, and declared the independence of the Federal Democratic Republic of Southern Cameroon (Konings \& Nyamnjoh, 1997). Whether Federal Democratic Republic of Southern Cameroon or the Federal Republic of Ambazonia, both appellations make reference to the same territorial space. Ambazonia was further popularized and internationalized as a territorial construct on October 1, 2017, when the Anglophone diaspora led Interim Government (IG) of Ambazonia headed by Sisiku Ayuk Julius Tabe (presently serving life sentence in Cameroon) unilaterally declared the independence of the country called Ambazonia, which was followed by mass civilian demonstrations across the North West and South West Regions of Cameron in acclamation (EUROACTIV, 2017). The conflict over the No-So heightened thereafter. It will however be important to present the geopolitical stakes of the crisis.

\section{The Geopolitical Stakes Of The Contested Territorial Space}

The Anglophone regions remain strategic to both the state of Cameroon and to the separatists. No-So is endowed with natural resources, fertile soils and climate which encourage extensive plantation agriculture of rubber, bananas, palm oil and tea. The No-So hosts some of the biggest Agricultural corporations in Cameroon. This part of the territory is also rich in timber and petroleum products (Lohkoko, 2013), and constitutes part of Cameroon's land and maritime frontiers. Thus, considering the fact that this study seeks to illuminate and provide deeper understanding of the geopolitical context of the Anglophone crisis, this section investigates the geopolitical stakes of the regions on the global, continental and local scales. 


\subsection{It's Geography}

Geographically, No-So is located west of the Mungo River. The territory is characterized by a series of volcanoes like the Mount Oku, Kupe Manenguba volcano, and the Mount Fako (Mt. Cameroon) with rich volcanic soils, making the regions rich in plantation agriculture. The Mt. Fako is the highest mountain in western Africa and the 28th highest in Africa as a whole (Gabche \& smaith, 2006). From Manyu Division, the disputed South West region shares border with Nigeria to the western part of Cameroon.

The Menchum Fall in the North West region was reputed as one of the most powerful waterfalls in Africa in the 1960's, although this changed due to deforestation and a resultant drop in water tables (Acho, 2017). However, the Ambazonian government considers the Menchum fall as a potential natural energy endowment. According to the AGovC, the Menchum fall, once harnessed after independence would provide the necessary uninterrupted electricity not only to Ambazonia, but enough to sell to even 'neighboring Cameroon' and Nigeria - both of whom suffer from inadequate electricity supply (Ayaba Cho Luca, for the Ambazonia Governing Council, July 16, 2019). The geography of the contested No-So therefore remained deeply rooted in the minds of the Ambazonia leadership as declared by the then Ambazonian Interim president- Sisiko Ayuk Julius Tabe during his 2017 "End of year address to the people of Ambazonia" over the Southern Cameroons Television in the following words; “...let's transform unity from the virtuality of social media platforms into realities... I mean the type of unity that we witnessed in the glorious days of the 22nd of September and the 1st of October 2017. The unity when our people rose as one; ... from every little corner of our land; from the borders of Mwa, to Akwaya and down to Bakassi [oil rich and border region with Nigeria], from the hilltop of Oku [on the Gulf of Guinea volcanic line] to the plains of Ndop [the agricultural hub of the region], from the shorelines of Victoria [along the Gulf of Guinea] to the mighty mount Fako [highest Mountain in West Africa]. Yes, unite, from the heartland of Manyu [hotspot of resistance and border region with Nigeria] where our people have shown tremendous resolve, and to the banks of the River Mungo [borderline with francophone Cameroon] where even nature reminds us that we no longer belong together. ..." (Southern Cameroons Television, December 31, 2017). This goes a long way to affirm the thesis that geographical images have become deeply rooted in political languages, and that political thoughts and geography are inevitably and irrevocably inter-twined (Young, 1987). It is therefore not surprising that the separatist leadership takes into account not only the historical and linguistic compositions of No-So, but also its geopolitical mapping. 


\subsubsection{The Gulf Of Guinea Factor}

Cameroon's coastline lies on the Bight of Biafra, part of the Gulf of Guinea and the Atlantic Ocean. Part of the Anglophone Regions (the Limbe Coastline) lies within the Gulf of Guinea. The Gulf of Guinea is the world's richest and under exploited place. It holds about $35 \%$ of the world's total petroleum reserves and blessed with many mineral and other natural resources such as diamonds, tin, bitumen, copper, manganese, gold, phosphide granite, gas just to mention these, as well as very rich rain forests which accounts for $20 \%$ of the world's total rainforest reserves (Abubakar, 2016).The Gulf of Guinea has a volcanic region known as the 'Island Arc' which is aligned with the Cameroon line of volcanoes (World Atlas, 2019), consisting of six offshore volcanic swells beginning with the Mount Cameroon in the South West Region (Kevin, 2001).

Due to geographical proximity and geopolitical linkages, the Gulf of Guinea member states have constituted a commission (made up of Angola, Cameroon, Republic of Congo, Democratic Republic of Congo, Gabon, Equatorial Guinea, Nigeria and Sao Tome and Principe) (Gulf of Guinea Commission, 2019), through which they cooperate significantly in their foreign and security policies. Hence, today, the Gulf of Guinea has a more geopolitical and geostrategic dimension, especially as a choke point for the shipping/transportation of oil extracted in the Niger Delta, as well as goods to and from Central and Southern Africa (Europa, 2018). As a town that lies along the Ambas Bay in the Gulf of Guinea (Encyclopedia Britannica, 2019), the Ambazonian government places Limbe at the core of their geopolitical web. According to the Ambazonian Interim government (IG), the town of Limbe is the link between West and Central Africa, strategically located in the armpit of Africa. Thus, the development of a deep-seaport in the town would assist the flow of goods to and from 'the country', making Ambazonia a major exporter of Agricultural products, considering the abundance of food and cash crops in the territory (https://psacs.org/what-we-do/ambazonia-naturalresources/ of 2019).

Also, the Ambazonian government valorizes the Limbe Atlantic coastline which according to them is rich in marine life and fishery potentials. The IG believes that fishing could be a major form of employment to the population, with an estimation of over 160.000tons of fish produced annually (www.ambazoniagov.org/index.phhp/state/fako-county, 2019). Fully cognizance of the active economic, diplomatic and military competition among the great powers (United States, Europe, China, Japan, India, Russia etc) in the region (Osaretin, 2011), the AGovC uses the Gulf of Guinea as a bargaining chip to attract the attention of the USA, for the role of the United State is increasing in the region, centered not only on securing the region's natural resources but also on its bourgeoning explosive markets (Ibid). Ayaba 
Cho Lucas (the commander in Chief of the Ambazonia Defense Force (ADF) and the leader of the Ambazonia Governing Council (AGovC)) in reaction to the life sentence slammed on Sisiku Ayuk Julius Tabe by the Cameroon government, declared "...the sentencing of our leaders was a slap on the face of the Americans... because the Americans have been the principal proponent of a negotiated settlement ... the only way American foreign interest can be served in the Gulf of Guinea is the recognition of Ambazonia, the only country that can ensure stability in the Gulf of Guinea, that can ensure international diplomacy... getting Ambazonia recognized is for the best interest of the international community..." (Ayaba Cho Lucas, August 25, 2019).

\subsection{Natural Resources}

'Sovereignty includes the right to extract and use resources' (Flint, 2006: 137) and 'states have to boost the development of their economies through the use of natural resources' (Kurecic, 2015: 2). Historically, most secession struggles in Africa (Katanga in Congo, Biafra in Nigeria etc as examples) have been linked to the presence of natural resources. The contested territory is endowed with a plethora of natural resources. It can be argued that presence of the natural resources remains a major driving force of those fighting for an independent Ambazonia. This is beautifully expressed in the "Ambazonian Anthem" in the following words; "... Here in our nation flowing with milk and honey..." (Millan Atem, September 16, 2017). Some of these perceived natural resources (milk and honey as referred) include; Petroleum, timber, rich soils for plantation agriculture, minerals, just to mention these. Blessed with natural resources therefore, the separatists believe that if exploited after independence, it would guarantee the economic sustainability and auto-centric development of Ambazonia. Below is a map representing the spatial distribution of economic zones in the anticipated Ambazonia as designed by the Ambazonian government and pasted on their website. 
Spatial Economic Zones of the Restive Anglophone Regions of Cameroon

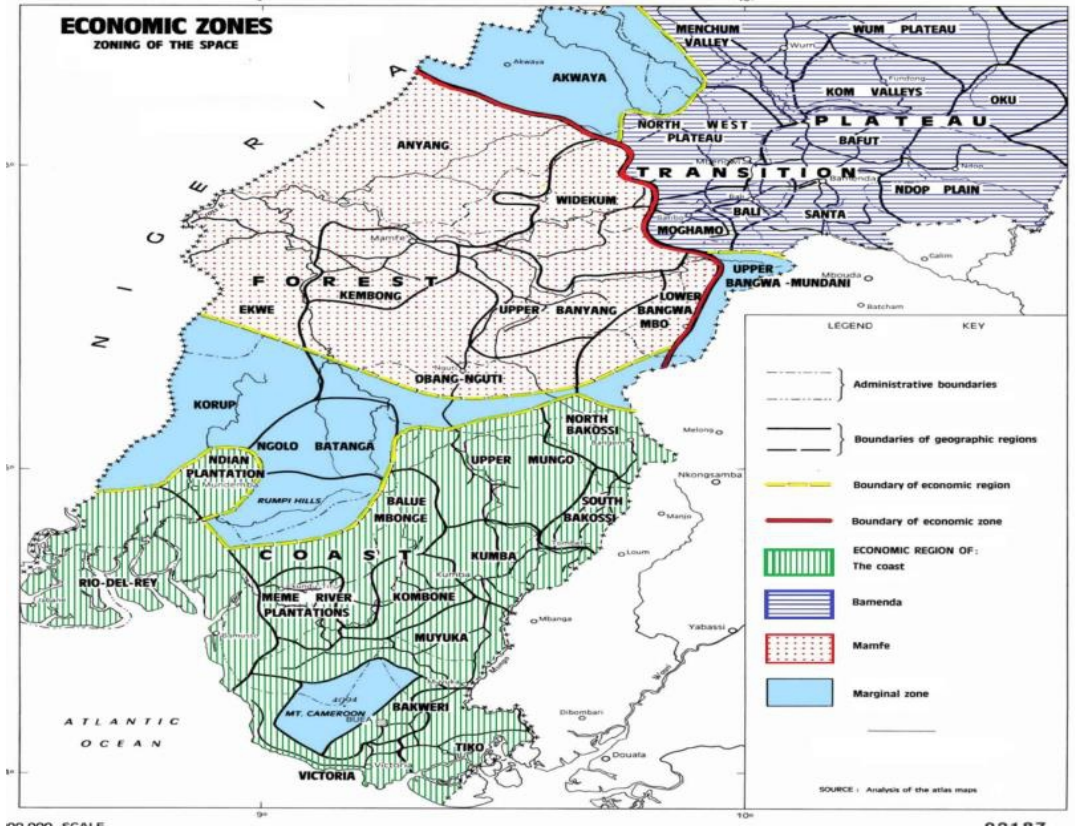

Source :https://www.ambazoniagov.org/images/Spatial_EconomicDevelopment.pnd.Retrieved August 22, 2019

\subsubsection{Forest Reserves}

The presence of forest reserves in the contested No-So is equally valorized by the Ambazonian leadership. Following information from the official website of the Ambazonian Interim Government (IG), the Kupe Muanenguba 'county' (in the South West Region) is dominated by dense equatorial forest, estimating that there is still a large amount of virgin forest mostly on the slopes of mount Kupe in the Tombel "Local Government Area" (LGA), with huge forest reserves around the same locality. The IG decries the extensive exploitation of timber from this part of "their territory" by the Cameroon government, but remains hopeful that despite this, Kupe Muanenguba still has a huge potential for timber exploitation (www.ambazoniagov.org/index.php/state/kupe-muanenguba-county, 2019). Furthermore, the IG estimates that forest reserves are found in all the three LGA in Ambazonia, and encompasses the largest cloud of forest in WestCentral Africa. Other earmarked reserves included the Ijim and Kom-Bum forest reserve, Kom-Wum forest reserve which spans from Belo in Boyo division to Menchum Division, with indications of other exploitable forests in the Manyu, Lebialem and Menka forest reserves, all found in No-So. To add, the IG's resource records has it that the Korup National Park in Ndian covering an area of $1,260 \mathrm{~km} 2$ of mostly pristine forest is reputed as one of Africa's 
oldest and richest rainforests in terms of flora and fauna diversity, attracting over 100.000 tourists to the Ndian Division annually (www.ambazoniagov.org).

\subsubsection{Mineral Resources}

The Ambazonian Interim Government ascertains the presence of mineral resources in the Kupe Muanengba 'County', including eight sand quarries, six pozzolana quarries, one pool paint, two mineral water sources and iron ore, the growing presence of world renowned Panja pepper as a cash crop along the volcanic flanks of the Mt. Kupe Muanenguba. Also, Basalt, commonly called "the black stone" was believed to be found in the Njinikom municipality in the North West Region. The IG equally projects the availability of gold in Misaje and Mamfe, iron ore, diamond, gold and gemstones located in Mayo Binka, and uranium in some localities. Again, they perceive the presence of limestone and marbles in Moko, Mbalangi in the South West Region, nepheline synenite located in Mamfe, as well as abundant granite and basalt (www.ambazoniagov.org). Believing in the presence of natural resources in No-So, the Ambazonian government remained optimistic for the survival of an independent nation.

\subsubsection{Limbe and the Petroleum factor}

The question of oil has become one of the most vital in all countries. Its importance is such that even the most solid political alliances in the world are subordinate to it. Thus, Oil probably has the clearest effect on conflict proneness (Kurecic, 2015).The contested zone hosts one of the largest oil and gas companies in Africa known in its French acronym SONARA (Societe Nationale de Raffinage), located in Limbe in the South West region of Cameroon. Founded in 1973, SONARA owns and operates the only crude oil refinery in Cameroon and produces butane, gasoline, jet fuel, kerosene, fuel oil and distillate, with the capacity of over two million tons a year. SONARA products are consumed in the national international markets (SONARA, 2019). Petroleum accounts for more than 50\% of the Cameroon's total export (Trading Economics, 2019).Meanwhile, according to Ayuk Julius Tabe in an interview granted to Lowell Telecommunication Corporation (in USA) in 2017,the Limbe oil wealth [which he referred to as Ambazonian oil] accounts for $60 \%$ of Cameroon's GDP (https://youtube.be/gvislA5rnek, of Sept. 25, 2017). This view was re-echoed by his successor, Samuel Ikome Sakoin 2018 over the Rudaw TV based in Washington DC in the USA (https://youtube.be/s4oXs7L7L0U, 2018).

Furthermore, the "Ayuk Tabe and Co Solidarity Organization" (An organization formed to secure the release of the jailed Ambazonian president and his cabinet) projects Ambazonia as the sixth largest oil producer in Sub- 
Saharan Africa, hoping to provide significant opportunities for exploration companies once independent is attained. The organization reveals the presence of millions of barrels in reserve of fossil fuels in Rio del Rey as well as in other places like Miselele basins, Mamfe and Bakassi Peninsular (https://psacs.org). This is used as a bargain by the Ambazonian leadership to source for foreign support via funding in exchange for exploration rights and business deals in a free Ambazonia.

The opportunity to loot or exploit resources is crucial for the possibility of an emergence of and/or sustainability of violent rebellions. This explains why the Ambazonian government had always sought for the possibility of trading 'their' resources for financial and or military support of the war to their favor. This equally brings to mind the secret agreement signed between a Canadian private company, Kilimanjaro Capital Ltd and a clandestine Separatist group in on November 1, 2012. According to a statement by Kilimanjaro Capital Ltd; "Kilimanjaro Capital Ltd... is pleased to announce that on 1 November 2012, it signed a formal Oil and Mineral Right Assignment with the Government of Southern Cameroons. Their region contains known petroleum reserves... The Assignment Agreement grants exclusive rights to cover an area of approximately 43,000 square kilometers... "(Ngoh, 2019: 388).In 2013, the CEO of Kilimanjaro Capital Ltd, Rashid Zulfikar appointed Ebenezer Akwanga (an Anglophone Cameroonian) as a member of the Advisory Board of the company. According to the 2017 report by the International Crisis Group (ICG), Ebenezer Akwanga was the commander of one of the rebel militia groups operating in the South West Region called the "Southern Cameroons Defence Forces" (SOCADEF) (Ibid).

\subsubsection{Agro-industrial potentials}

The South West region hosts the biggest Para-state Corporation in Cameroon; the Cameroon Development Corporation (CDC). The CDC is an Agro-Industrial Enterprise created in 1946 to acquire, develop and operate extensive plantations of tropical crops. The corporation grows three tropical crops namely Rubber, Oil Palm and Banana, with its headquarters on Limbe in the South West Regions. Its plantations cover a total of approximately 41,000 Hectares of land The corporation operate 9 Rubber Estates, Oil Palm Estates, 5 Rubber Factories and 2 Palm Oil Mills. It constitutes a workforce of over 22.000 employees, making it the second highest employer after the state of Cameroon (Cameroon in Business, 2016).

In the course of the crisis, the separatist fighters ensured the permanent closure of the CDC in a bid to cripple the government economically. As reported by the International Crisis Group, in July 2018, the Cameroon Employers Association (GICAM) estimated the value of losses incurred by the CDC at FCFA 269 billion (€410 million) (International Crisis group, May 
2, 2019). This was achieved via brutal treatment of the plantation workers. In November 2018, CDC workers saw their fingers chopped off in Tiko (Cameroon Daily Journal, November, 2018), and on February 19, 2019, at least six others had their fingers chopped off still in Tiko, South West region (Journal du Cameroun, February 19, 2019). Thus, due to threats from separatists, plantation workers had to abandon work, as confirmed by the General Manager of the CDC in January 2019 in the following words, "In most of the estates, the workers have abandoned work; the crops such as bananas, rubber, palm, now have been overgrown by grass. Other structures of the corporation have been vandalized and some burnt down"'(The National Times, January 22, 2019). Such a declaration went a long way to suit the separatist agenda of economic sabotage. As such, in reaction to the downward shoot of the CDC, Ayaba Cho Lucas intimated; “... we have stopped one of the greatest corporations [CDC] they [Cameroon] have been generating money from to feed their army against Ambazonia..." (Ayaba Cho Lucas, August 25, 2019).

Considering the fact that the $\mathrm{CDC}$ was the pride of the West Cameroonians in the 1960's (Ngoh, 2019), and with the agricultural sector accounting for about $63.4 \%$ of the gross domestic product of the state of West Cameroon (Ebune, 2016),the IG still believes that the agro-industrial potentials of Ambazonia remains imminent for the survival of the nation after independence. The agro-industrial potentials of No-So are clearly mapped out by the Ambazonian leadership in the map below. 


\section{Agro-industrial Potentials of the Restive Anglophone Regions}

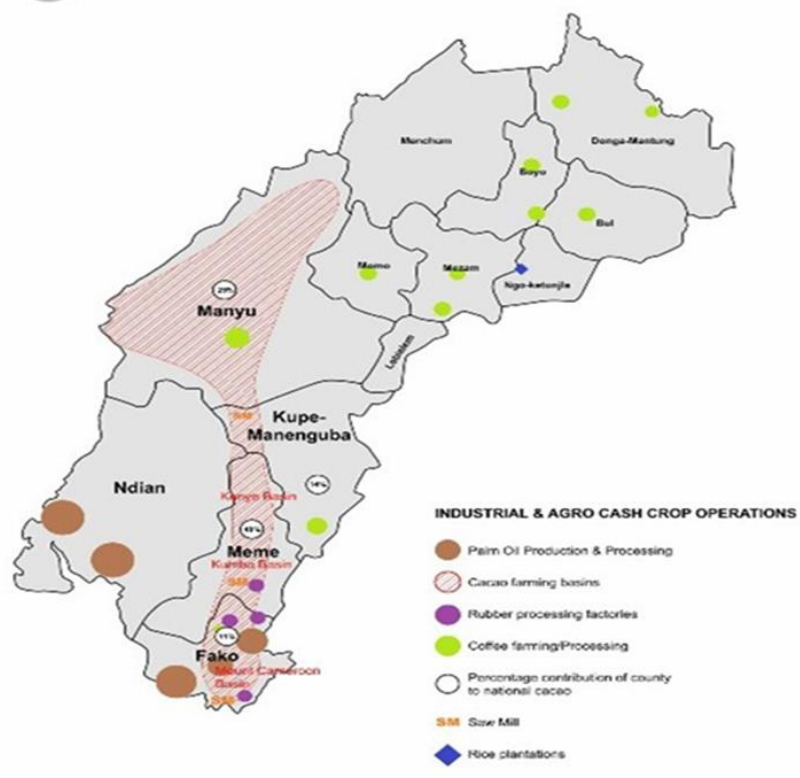

Source: https://www.ambazoniagov.org/images/Agro-industy.jpg.

Retrieved August 22, 2019

\subsection{The Cameroon/Nigerian frontiers factor}

'The correlation between internal conflicts and their cross border dimensions is an important variable that should not be neglected' (Anderson \& O'Dowd, 1999: 596), and the 'effective control of the boundaries provides the legitimacy and power of the state' (Flint, 2006: 136).The instability and conflict in the border regions is associated with the inevitable involvement in their struggle with metropolitan country. It is statistically proven that if a country is bordered by a belligerent neighbor, the probability of that country being drawn into a conflict is three times higher than for other countries. This is particularly common in the case of nations with complex mosaic structures of ethnicity (Sevastianov, Laine \& Kireev, 2019) as the case of Nigeria and Cameroon. The English sections of Cameroon shares a common boundary with the Biafra dominated Eastern Region of Nigeria, which had clamored for independence from the Nigerian Federation leading to the Biafran Civil War of 1967 - 1970 (Chidiebere, 2016).

Thus, both the Biafrans in Nigeria and Anglophones in Cameroon have a common history of secessionist tendencies. Coincidentally, they are geographically situated at both sides of the borders between Cameroon and Nigeria. This poses a risk factor as one can influence the other if at all a possible alliance is not an option. It remains worrisome that 50 years after the Biafra civil war, there was the resurgence of protests in the Biafra region (in 
2017), calling for independence (News24, 2017), coinciding with the heightening of the Anglophone crisis. This therefore renders the Cameroon/Nigeria border very strategic, for, the borders of countries in violent conflicts may be associated with risks such as the use of the border territories as a corridor for the supply of weapons or as a refuge for the rebels (Sevastianov, Laine, \& Kireev, 2019), or as a proxy zones for sporadic guerrilla attacks. This was evident in January 2018, following an attack on the Ekok border crossing connecting Nigeria's Cross River state and the South West Region of Cameroon. The attack saw the use of explosives, with assailants reported to have approached from the Nigerian side of the border, though refuted by the Nigerian government who claimed to have spotted armed men on the Cameroonian side of the border (GardaWorld, January 26, 2018). Also, according to the Cameroonian military, they intercepted hundreds of Nigerians fighters from crossing into Cameroon in October 2017 (Kindzeka, October 9, 2017). In the same light, in January 2019, three persons were arrested along the Cameroon/Nigeria border for allegedly trafficking ammunition into Cameroon. As reported by security forces, bullets were transported in bags of groundnuts on board a travel agency heading from Nigeria to Bamenda in the North West Region of Cameroon (Journal du Cameroun, October 25, 2017). One thing remains clear; the separatist fighters were ready to exploit the eventuality of a porous border zone between both countries.

With the risk of possible cooperation between the secessionists of both countries, especially with Nigeria already acting as a breeding ground for Ambazonian leadership, both the Cameroonian and Nigerian governments were forced to intensify diplomatic and trans-border military cooperation. The outcome of this cooperation was the arrest of the Ambazonian leadership in Nigeria and their subsequent extradition to Cameroon (Unindependent Nations and Peoples Organization (UNPO), March 26, 2018). Such cooperation between Cameroon and Nigeria could not have been avoided for three reasons; the first being that they are both threatened by secessionist movements. Secondly, the northern parts of both countries remain threatened by Boko Haram insurgencies. Thirdly, trans-border regions are normally characterized by the dominance of simple and locally limited interactions and trade exchanges. Trans-border cooperation between Cameroon and Nigeria through the town of Mamfe (a Cameroonian border town with Nigeria) has always favored improved cooperation between both countries.

Equally, the Anglophone separatists have been disappointed with the Cameroonian government for several economic and geopolitical reasons. Considering the fact that Nigeria is one of Cameroon's major trading partners(World Bank Report, 2017), the separatists perceive that in case of an independent Ambazonia, trade negotiation with Nigeria will be a top priority. 
Furthermore, the Cameroon government's approach to regional integration is at odds with the separatists. Cameroon is a founding member of CEMAC (Economic and Monetary Community of Central African States) which is against the aspirations of the separatist. The separatists prefer Ambazonia to be a member of ECOWAS (Economic Community of West African States) which has a larger market, and with a population of close to 300million people (Elong, 2014), with Nigeria (Ambazonian western neighbor) being the most populous nation in the sub-region. According to the separatists, the survival of an independent Ambazonia rests on access to the ECOWAS region since to them, Ambazonia is located in the West and not the Central African sub-region (Federal Republic of Ambazonia, July 16, 2019).

\subsection{Demographic Considerations}

'Significant size of population allows a state to be granted the status of a player in the international political field due to the fact that the population provides manpower for economic development and military strength' (Bezverbny, n.d.: 6). Looking at Nigeria for example, we see a political giant as far as the African continent is concerned due to its population size. Cameroon has a total population of over 25 million inhabitants, occupying the 52nd position in the world population ranking, 17th most populous country in Africa (World Population Review, 2019) and the most populous country within the CEMAC sub-region. Thus, Cameroon's leading role in the CEMAC is partly due to the fact that it is the most populous nation within the subregion. Furthermore, because of its French and English colonial history, Cameroon is considered a bilingual country with its population speaking both English and French (Cameroon Economic Update, 2011). The activities of the separatists remained a threat to Cameroon's demographic status quo.

Even though no official figure currently exists on the exact population size of the English speaking regions of Cameroon, according to the Anglophone separatists, the current population of No-So (Ambazonia) is more than 8million inhabitants. Based on this figure, they claim the right to independence, since to them, it makes Ambazonia to be more populous than 60 United Nations (UN) member state and18 African Union (AU) member states, and with a land size $43,000 \mathrm{sq}$. $\mathrm{km}$ larger than that of $30 \mathrm{UN}$ member states and 12 AU member states (Federal Republic of Ambazonia, July 16, 2019).

From the above analysis, it can be argued that the quest for secession is not all about meeting up with historical blunders or the mere fighting for autonomy. The geopolitical undertones cannot be undermined, for, this drive is equally encouraged by the presence of natural resources, the geography and demography of the restive zones. The resources endowed in these regions and in the entire nation have equally influences to great deal Cameroon's 
diplomatic and economic relations with the great powers, and hence, their positions as far as resolving the crisis is concerned. Thus, the next section of this paper seeks to examine the involvement of some of the great powers in protecting their interests in the midst of the Anglophone crisis.

\section{3. 'Great Power' Geopolitical Stakes In Heightening Anglophone Crisis}

It is important to mention that the separatists look up to the great powers (America, Britain, France Russia and China) for rescue and eventual recognition of their independence. Meanwhile, these great powers recognize the territorial integrity of Cameroon and hence No-So as part of the country's territorial space, and validate the government's efforts in resolving the crisis within the framework of a united Cameroon. As part of the plans to realize vision 2035, the Biya's government has further created more foreign investment avenues in the country, with the great powers prioritized as major cooperation partners. It can therefore be argued that despite the deterioration of the crisis, Cameroon remains a chessboard on which the great powers continued to manifest their interest through bilateral and multilateral cooperation. Hence, a critical and deep understanding of some of the great power involvements (notably, the former colonial masters of Cameroon) and their stance in the crisis requires proper diagnoses.

\subsection{France}

Since independence, France has remained Cameroon's leading partner and the geopolitical interest of France in the territory are abound. Without probing into the rich historical ties between both countries, French interest in the territory is visible in the oil, cement, wood construction, telecommunication sectors in Cameroon. Leading French companies in the territory are the Bollore Group in agriculture and agribusiness as well as logistics and transportation, Total and Perenco in oil, Orange for mobile telephony, Bouuygues, Razel, SCET for construction, just to mention these (Business in Cameroon, July 15, 2010), with a consortium of French firms working for the improvement of fuel production in SONARA in the South West Region since 2017 (Brelsford, 2017, 2017).These amongst others therefore explain the strong bilateral ties between Cameroon and France in varied domains. As such, the French condemned Separatist attacks on soldiers, called for dialogue to ensure the unity of Cameroon, supported peace efforts of the Cameroon government during the informal United Nations Security Council Meeting held in May 2019(UN Web TV, May 13, 2019), maintained military cooperation with Cameroon government, and provided the Cameroon government with the much needed finances and logistics to ensure stability within the restive regions (Voice of America, February 7, 2019).Meanwhile, 
the Ambazonian Governing Council (AGovC) considers that the French are using Cameroon to exploit their territory and as a proxy to fight Ambazonia. The AGovC declared; “... the French government of Emmanuel Macron; the unseen but economic and political influence within French Cameroun must now understand that their proxy war in Ambazonia is NOT only unwinnable but is going to be economically costly on her relationship with Yaounde. ..." (Ayaba Cho Lucas, for the Ambazonia Governing Council, July 16, 2019). However, despite the French concerns on the deteriorating human right situations in No-So and the need for dialogue as expressed by the French minister of Europe and Foreign Affairs in July 2019 (Journal du Cameroun, July 31, 2019), the bilateral relationship between Yaounde and Paris remain unabated.

\subsection{Britain}

The Ambazonian leadership strongly believes that the UK, as a former colonial power retains responsibility for what happens to its former subjects. As such, they looked up to Britain to complete the decolonization process of her former territory of British Southern Cameroon, by facilitating the recognition of the independence of Ambazonia. But then, 'successive UK governments have resisted this view' (Lunn \& Brooke-Holland, 2019: 13).However, despite the British support for dialogue, the outcome of her bilateral relations with the Cameroon government amidst the crisis spoke volume as far as British geopolitical interest in the restive zones was concerned. While the UK continued to monitor the crisis, in 2018, British Trade Secretary-Liam Fox announced the successful sealing of a £1.5billion trade deal secured by a UK oil and company (New Age Company) with Cameroon, for the delivery of a floating natural gas project at Etimde in Limbe in the restive South West Region of Cameroon. The deal came after a meeting between the British Trade Minister-Boaroness Fairhead and the Secretary General at Cameroon's presidency. The deal was described by the Cameroon Intelligence Report News as "Blood Gas" (Cameroon Intelligence Report, June 9, 2018).

While battling for Brexit, the British government is highly committed to securing geopolitical sphere in order to boost the UK economy after the Brexit (Stinson, 2019). This commitment was intimated by the British Department for International Trade headed by Liam Fox after the Cameroon deal, in the following words; "These projects are just the tip of the iceberg, with huge scope for more British companies to target overseas markets" (Offshore Energy Today, June 12, 2018).British interest was further buttressed by Conservative party member-Peer Baroness, responding for the UK government in a debate on the deteriorating situation in Cameroon vis-a-vis the oil deal. He told the House of Lords; "we do not see that there has to be a 
choice between securing growth and investment for the $U K$, and raising human rights..."(Cameroon Intelligence Report, December 18, 2018). Meanwhile, according to the AGovC, such a deal was a threat, and interpreted Britain's noncompliance to ensuring the complete independence of their former colony [of British Southern Cameroon] as a desire to save Cameroun and by extension their economic interest within Ambazonia. Thus, the AGovC declared; "...Ambazonia represents a better environment for future economic relationship... does not endorse their [British] economic exploration and exploitation through agreements with Cameroun, but does not mean that we will not engage them [Britain] in our future business relationships... it is therefore the moral responsibility for Britain and the world at large to recognize the clear violation of not only our history but our RIGHT TO SELF RULE. In a free Ambazonia, we will not only guarantee security with the global context of fighting terrorism but also provide one of the most healthy environment for world trade and commerce."(Ayaba Cho Lucas, for the Ambazonia Governing Council, July 16, 2019).

Spatial view of the Etimde gas field (MLHP-7)

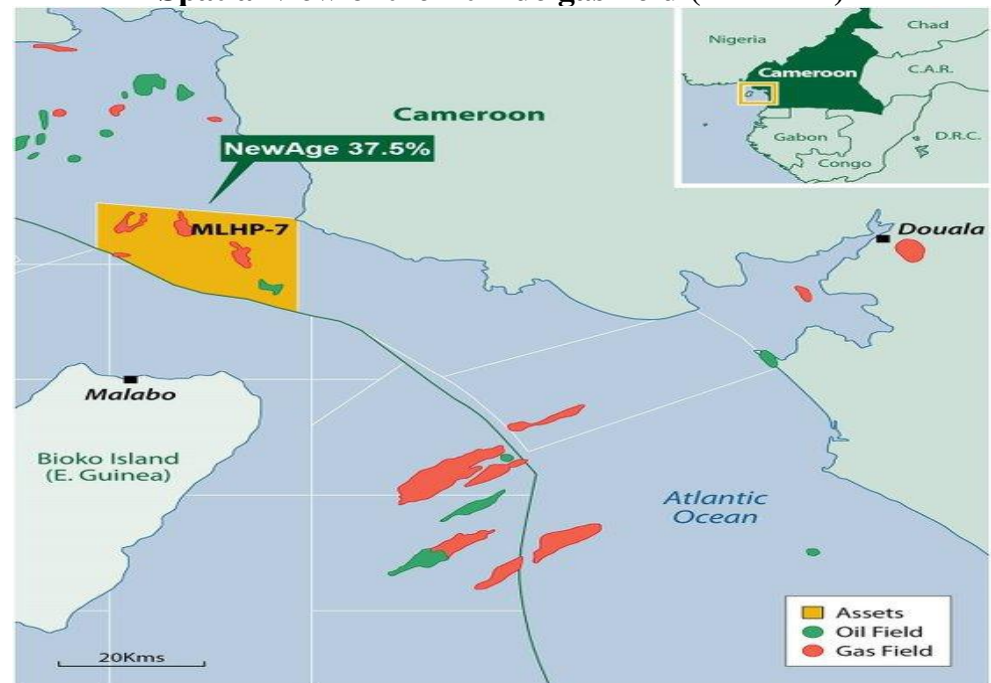

Source: http://mobile.twitter.com/EmmanuelFreuden/status/1005150740644597760.

Retrieved August 22, 2019

From the above analysis, it remains problematic to the Anglophone separatists that the aforementioned resources are managed by the government of Cameroon. This is compounded by the fact that they do not feel that they are adequately benefiting from those resources though hugely found in "their territory". This has therefore resulted to the emergence collective sense regret and nostalgia of pre-1972 Anglophone Cameroon. 


\section{Historical Memories}

In explaining the 'organic theory', Frederic Ratzel extrapolates the idea of a solid historical link between a people and the area they live. He called it; 'organic territoriality' which according to him refers to a socially constructed idea and perception that a political group is historically rooted to the soil they are living on (Vollaard, 2007). The Anglophone separatists and a handful of Anglophone Cameroonians still have fresh memories of pre-1972 West Cameroon (Anglophone Cameroon under the Federal Republic of 1961 - 1972), characterized by vibrant economic ventures which were later rendered defunct by the Ahidjo and Biya's governments. These historic imaginations cannot be negligible in the analysis of the current crisis. This view could be buttressed by the following declaration by Sisiku Ayuk Julius; “...all our institutions have crumbled, they've taken away everything that makes us human, ... even the simple institutions on our land have been destroyed, we had two airports, as we speak you cannot land on a plan to our soil, there's a deep seaport in our land abandoned to a seaport in Douala, today there are 38 oil blocks in operation in Cameroon, 30 of them happen to be in Southern Cameroons. They built a refinery on our land and they channeled a depot of the oil on their land..." (Lowell Telecommunication Corporation, September 25, 2017). Some defunct economic ventures that reflect the historical memories of the separatists are expressed by the Anbazonian government in the map bellow.

Separatist mapping of defunct economic projects in former west Cameroon

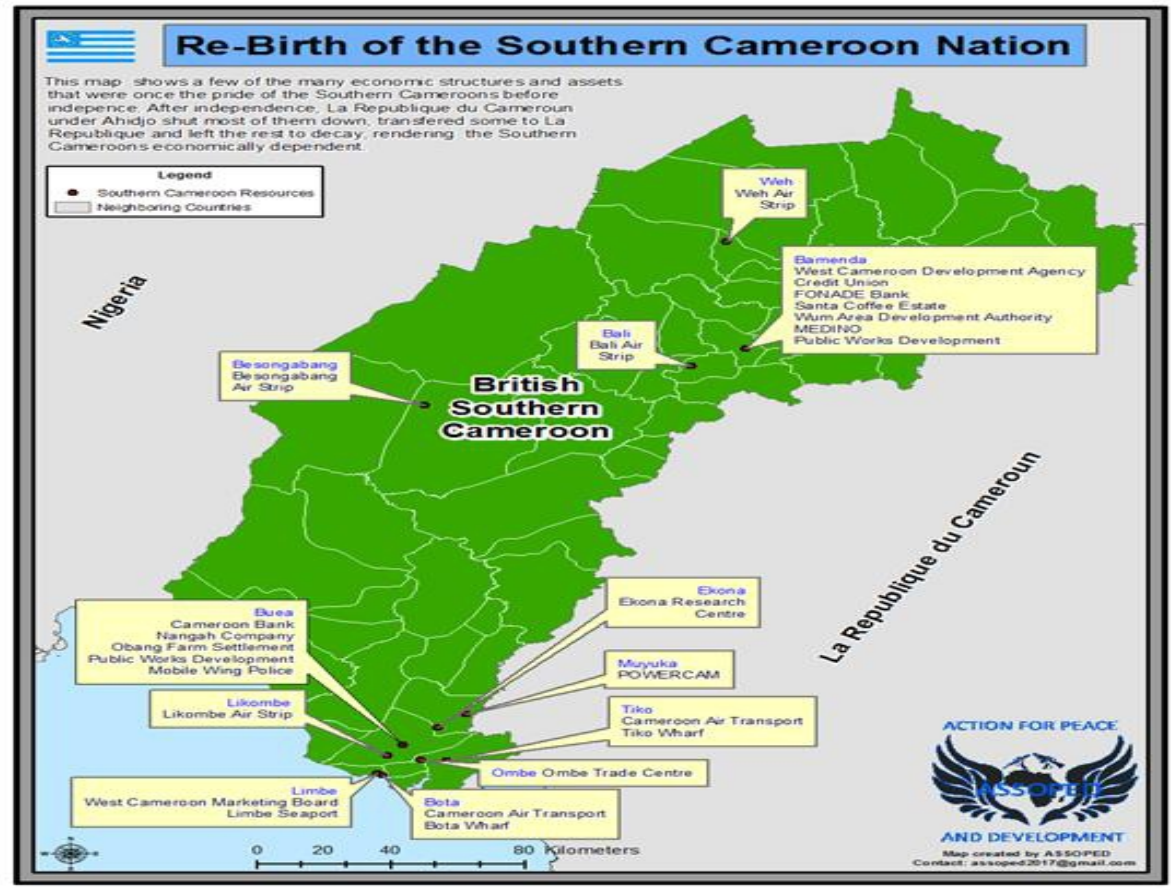

Source: https://www.ambazoniagov.org/images/. Retrieved August 22, 2019 
As on the map, there are a plethora of economic projects that remain in the minds of the separatists and many ordinary Anglophone Cameroonians, who accused the government of destroying in favor of Francophone dominated institutions. Thus, the vision of reviving such projects in an independent Ambazonia remains a fundamental item on the separatist's post-independence agenda. Some of these defunct projects include the following;

- Cameroon Bank (CB), which guaranteed the financial autonomy of former west Cameroon, the Powercam, which was in charge of the distribution of pipe-born water in former West Cameroon (Ndobegang, 2009).

- The West Cameroon Development Agency (WCDA), which was the structure responsible for economic developments in former West Cameroon (Ebune, 2016).

- Other institutions that had been destroyed in favour of those based in the Francophone regions included the West Cameroon Marketing Board; the Santa Coffee Estate; the Yoke Power Station; the Tiko, Victoria and Mamfe sea/river ports, the Tiko, Bisongabang, and Bali airports, amongst others (Fonchingong, 2013).

The above projects were rendered defunct by the Ahidjo and Biya's regime after the abolition of the Cameroon Federation in 1972. Little wonder, post 1972 therefore undoubtedly marked the genesis of Anglophone agitations and the resultant reawakening of sentiments of a nostalgic historical past. Such sentiments provoked the declaration of the restoration of the independence of Southern Cameroon (Ambazonia) on October 1, 2017.

\section{Conclusion}

In this paper, the geopolitical undertones of the Anglophone crisis in Cameroon have been examined. This however does not discard the other dimensions of the crisis (Historical, cultural etc). A geopolitical analysis takes into account the interplay between geography, history and political power. These components have been proven to be deeply rooted in the crisis. Hence, this paper has examined the strategic geographical location of the restive NoSo; its location at the Gulf of Guinea and its Atlantic coastline which provides access to the rest of the world. It has been ascertained that the separatists rely on the availability of natural resource such as petroleum for the sustenance of an independent Ambazonia. Meanwhile, demographically, they consider the population of the No-So as large enough to be granted the status of an independent nation. These considerations are undoubtedly great motivating factors to the separatists in their quest for an independent Ambazonia. However, No-So still remains part of the territorial space of the Republic of Cameroon considering the fact that Ambazonia is not recognized internationally as a sovereign state. 


\section{References:}

1. Abubakar, B. (2016). Gulf of Guinea Resources, Economy and Development: Yesterday, Today and Tomorrow. ResearchGate. P. 3. Retrieved August 20, 2019, from https://www.researchgate.net/publication/320806876_Gulf_of_G uinea_Resources_Economy_and_Developmnt_Yesterday_Today and_Tomorrow.

2. Acho, Y. (2017). The Menchum Fall: cameroon's Rural Electrification Power Resevoir. Retrieved September 1, 2019, from https://yalaafricapress.worldpress.com/217/10/13/themenchum-fall-cameroons-rural-electrificatin-power-resevoir/.

3. Anderson, J. \& O’Dowd, L. (1999). Borders, Border Regions and Territoriality: Contradictory Meanings, Changing Significance, Regional Studies. Vol. 33, no. 7, p. 596.

4. Ambazonia. (2019). In Wikipedia. Retreived July 22, 2019, from https://en.m.wikipedia.org/wiki/Ambazonia.

5. Ayaba Cho Lucas. (2019, August 25). The new found war partner and sentencing of Sisiku, lockdown. [Video file]. Retrieved August 27, 2019, from https://m.facebook.com/ayaba.lucas?fref=nf.

6. Ayaba Cho Luca, for the Ambazonia Governing Council. (2019, July 16). Only the Recognition of Ambazonia will instantly stop the war". [Facebook post]. Retrieved August 23, 2019, from https://m.facebook.com/BaretaNews/posts/only-the-recognitionof-ambazonia-will-instantly-stop-the-war-the-recognitionof/2261418317268806/.

7. Bezverbny, V. (n.d.). Geopolitics of population: How the Demographic Processes are Shapping National Power. Institute of Social and Political Research, Russian Academy of Sciences (Moscow). P. 6.

8. Business in Cameroon. (2010, July 15). France, Cameroon's main Partner. Retrieved August 7, 2019, from businesscameroon.com/in-focus/france-cameroons-main-partner.

9. Burnley, J. (2016). The Early Times in Victoria (Limbe). Retrieved September 18 , 2019,fromhttps://web.archives.org/web/20160307204612/http://w ww.bakweri.org/2007/03/the_early_times.html.

10. Cahnman, J. W. (1943). Concepts of Geopolitics. American Sociological Review, Vol. 8, No. 1, p. 57.

11. Cameroon Daily Journal. (2018, November). See sad Images of all CDC workers with Fingers Chopped off by Amba Boys. Retrieved September 1, 2019, from https://cameroondailyjournal.com/see- 
sad-images-of-all-cdc-workers-with-fingers-chopped-up-byamba-boys/.

12. Cameroon Development Corporation. (2019). The Company. Retrieved July 24, 2019, from www.northwestcameroon.com/home-140-inner-141.html.

13. Cameroon Economic Update. (2011) "Time for the lion to Wake Up? An Economic Update on Cameroon: With a focus on Telecoms," Poverty Reduction and Economic Management Unit Africa Region, January 2011, Issue No. 1, p. 3.

14. Cameroon in Business (2016). Cameroon: the state of Cameroon takes full control of agro-industrial CDC and opens the way for diversity. Retrieve July 24, 2019 from https://www.businessincameroon.com.

15. Cameroon Intelligence Report. (2018, June 9). Blood Gas:UK signs $£ 1.5 B i l l i o n$ trade deal with Biya. Retrieved August 22, 2019, from www.cameroonintelligencereport.com/blood-gas-uk-signes1-5billion-trade-deal-with-biya/.

16. Cameroon Intelligence Report.(2018, December 18). Ambazonia: Do UK business links really open channels to raise human rights concerns?. Retrieved August 22, 2019, from https://www.cameroonintelligencereport.com/ambazonia-do-ukbusiness-links-really-open-channels-to-raise-human-rightsconcern.

17. Chidiebere, O. (2016). The Nigerian Civil War: A Historical Interpretation. Pyrex Journal of African Studies and Development. P. 30 .

18. Dijkink, G. (1996). National Identity and Geopolitical Visions. Routledge. P. 5

19. Dodds, K. (2007). Geopolitics: A Very Short Introduction, New York: Oxford University Press, p. 4.

20. Ebune, B. J. (2016). The Dilemma of the Federal System in West Cameroon,1961-1972. Journal of Scientific Research and StuduesVol 3(7). Pp. 133-137.

21. Elong, E. E. (2014). Sovereignty in the Making: The Case of Anglophone Cameroon. ResearchGate. Retrieved July 27, 2019, from https://www.researchgate.net/publication/269575409.

22. Encyclopedia Britannica. (2019). Limbe-Cameroon. Retrieved August 20,2019, from https://britannica.com/place/LimbeCameroon.

23. EUROACTIV. (2017, September 10). Several killed in Cameroon as Anglophones declared 'independent Ambazonia'. Retrieved August 30 , 2019 , 
fromhttp://www.euroactiv.com/sectin/languages-

culture/news/several-killed-in-cameroon-as-anglophones-declareindependenct-ambazonia/.

24. Europa. (2018, October 29). EU maritime Security Factsheet: The Gulf of Guinea. Retrieved August 20,2019, from https://europa.euheadquarters/headquarters-Homepage/52490/eumaritime-security-factsheet-gulf-guinea_en.

25. Federal Republic of Ambazonia. (2019). 'Position Statement of the People of Former British Southern Cameroons/Ambazonia'. Presented to the Former African Heads of state Regarding Africa Constitutive Act 4(b) for Security, during their Proposed Symposium on 'the Crisis in Cameroon', Addis Ababa, July 16, 2019. P. 5.

26. Flint, C. ( 2006). Introduction to Geopolitics. Routledge, Madison Ave, New York. P. 136-137.

27. Fonchingong, T. (2013). The quest for autonomy: The case of Anglophone Cameroon. African Journal of Political Science and International Relations, Vol. 7(5), pp. 224-236.

28. Gabche, C. E \&smaith, S. V. (2006). Cameroon Estuarine System. Retrieved September 1, 2019, from nest.su.se/mnode/Africa/Cameroon/Cameroon intro.html

29. GardaWorld. (2018, January 26). Cameroon/Nigeria: Attack at Ekok border crossing Jan. 25. Retrieved August 6, 2019, from http://www.gard.com/fr/crisis24/alertess-desecurite/87731/cameroonNigeria-attack-at-ekok-border-crossingJan-25.

30. Gottmann, J. (1973), The Significance of Territory. Charlottesville. University of Virginia Press. pp. 5- 26.

31. Gulf of Guinea Commission (2019). Member States. Retrieved August 20,2019, from http://cggrps.com/en/the-gulf-of-guineacommission/\#.

32. Guzzini, S. (2010). Self-fulfilling geopolitics? Or: The Social Production of Foreign Policy Expertise in Europe. Danish Institute for International Studies. P. 14.

33. Interim Government of Ambazonia. (n.d.). Fako County: Resources. Retrieved August 6, 2019, from www.ambazoniagov.org/index.phhp/state/fako-county.

34. International Crisis group (2019, May 2). Cameroon's Anglophone Crisis: How to Get to Talks?. Retrieved August 24, 2019, from https://www.crisisgroup.org/africa/central-africa/cameroon/272crisis-anglophone-ou-cameroun-comment-arrive-aux-pourparlers. 
35. Jones, M, Jones, R \& Woods, M. (2004). An Introduction to Political Geography: Space, Place and Politics. Routledge. P. 170.

36. Journal du Cameroun. (2019, July 31). France issues Cameroon crisis warning. Retrieved September 18, 2019, from https://www.journalducameroun.com/en/france-issues-camerooncrisis-warning/.

37. Journal du Cameroun. (2019, February 19). Cameroon: Gunmen chop off fingers of plantation workers in Tiko. Retrieved August 3, 2019, from https://www.journalducameroun.com/en/cameroongunmen-chop-off-fingers-of-plantation-workers-in-tiko/.

38. Journal du Cameroun.(2017, October 25). Cameroonian: Three arrested over bullet-trafficking in Mamfe. Retrieved from, http://m.dw.com/en/cameroonian-three-arrested-over-bullettrafficking-in-mamfe/.

39. Kevin, K. (2001). Origin of thee Cameroon Line of Volcanocapped Swells. The Journal of Geology. Pp 349-351.

40. Kindzeka, E. M. (2017, October 9). Cameroonian troops deploy heavily along Nigerian border. Retrieved from, http://m.dw.com/en/cameroonian-troops-deploy-heavily-alongnigeria-border/a-40977538.

41. Konings, P. \&Nyamnjoh,B. F. (1997). The Anglophone Problem in Cameroon. The Journal of Modern African Studies, 35, 2.Pp. 207-229.

42. Kurecic, P. (2015 ). Geoeconomic and Geopolitical Conflicts: Outcomes of the Geopolitical Economy in a Contemporary World. Pluto Journals. P. 2

43. Lohkoko, E. A. (2013). Cameroon: A Conflict Profile. Conflict Studies Quarterly, p. 29.

44. Lowell Telecommunication Corporation. (2017, September 25). Lowell Southern Cameroon Discuss [video file]. Retrieved August 24, 2019, from https://youtube.be/gvislA5rnek.

45. Lunn, J \& Brooke-Holland, L. (2019 April 17). The Anglophone Cameroon crisis: April 2019 update. Briefing Paper Number 8331. House of Commons Library. P. 13.

46. MillanAtem. (2017, September 16). The Ambazonia Anthem. [Facebook page]. Retrieved August 6, 2019, from https://m.facebook.com/SG.millanAtem/posts/118269198842577.

47. Mirko, P \&Wehrmann, D. (2015). “Geopolitics”. In InterAmerican Wiki: Terms - Concepts -Critical Perspectives. Retrieved July 25, 2019, from https://www.unibielefeld.de/cias/wiki/g_Geopolitics.html. 
48. News24. (2017). Security forces, pro-Biafra group clash in South East Nigeria. Retrieved July 26, 2019, from https://m.news24.com/security-forces-pro-biafra-group-clash-inse-nigeria-20170914.

49. Ndobegang, M. (2009). "The Anglophone-Francophone Divide in Cameroon: Diagnoses of a National Disconnection" in http://public.unionky.edu/fulbright/file/2009/07/the-anglophonefrancophone-divide-in-cameroon.pdf. p.4.

50. Ngoh, V. J. (2004). Politics in Francophone Africa. Lynne Rienner Publishers. P.6.

51. Ngoh, V.J. (2019). Cameroon 1884 - present (2018) The History of a People. Design House, Limbe, Cameroon. p. 388.

52. Nicole Stinson. (2019, June 9). UK signs £1.5Billion trade deal as Brexit Britain expands on world stage. Express News. Retrieved August 22, 2019, from https://www.expressnews.co.uk/news/uk/971445/brexit-news-euuk-trade-deals-liam-fox-cameroon-trade-deal-india-turkey/amp.

53. Offshore Energy Today. (2018, June 12). Report: New Age pens deal to develop Etinde field using FLNG unit (Cameroon). Retrieved August 22, 2019, from https://mobile.offshoreenergytoday.com/report-new-age-pensdeal-to-develop-etinde-field-using-flng unit-cameroon/.

54. Osaretin, I. (2011) From Latent to the Manifest: US Strategic Interest in the Gulf of Guinea. Journal of Social Sciences. P. 125.

55. PSACS. (2019). Ambazonia Natural Resources. Retrieved August 7, 2019, from https://psacs.org/what-we-do/ambazonia-naturalresources/.

56. Reuters World News. (2018, February 2). France condemns Killings in Cameroon, Urges Dialogue. Retrieved September 17, 2019, from https://reuters.com/article/us-cameroon-separatistsfrance-france-condemns-killings-in-cameroon-urges-dialogueidUSKBN1FM1VL.

57. Robert Brelsford. (2017, July 27). Cameroon's SONARA lets contract for Limbe refinery. Oil \&Gaz Journal. Retrieved August 7, 2019, from http://www.ogj.com/refiningprocessing/article/17289642/cameroons-sonara-lets-contract-forlimbe-refinery.

58. Rudaw TV, Washington (2018). Exclusive interview with Ambazonia acting president. [Video file]. Retrieved August 24, 2019, from https://youtube.be/s4oXs7L7L0U. 
59. Sevastianov, V. S, Laine, P. J, \&Kireev, A. A. (Eds.). (2019). Introduction to Border Studies. Vladivostok: Dalnauka, ISBN 9785-8044-1579-3.

60. SONARA. (n.d.). SONARA in a Few Words. Retrieved September 1, 2019, from https://sonara-cm.com/en/.

61. Storey, D. (2017) Territory and Territoriality. Oxford Bibliographies. Retrieved July 21, 2019, from oxfordbibliographies.com/view/document/obo9780199874002/obo-9780199874002-007.xml.

62. The National Times. (January 22, 2019). No amount of Money Can Rescue the CDC without Security Assurance, GM Insists. Retrieved September 1, 2019, from natimesnews.com/no-amountof-money-can-rescue-the-cdc-without-security-assurance-gm insistslimbenational-times-the-pride-of-anglophone-cameroonthe Cameroon-development-corporaion-cdc-is-ast-collaspsing-ifnothing/.

63. Toal, G. (1996). Critical Geopolitics: The Politics of Writing Global Space, London: Routledge. P. 2.

64. Toal, G. (2009). quoted in Efferink, V. L. Definition of Geopolitics. Retrieved August 3, 2019, from http://www.exploringgeopolitics.org/publication_efferink_van_le onhardt_the_definition_of_geopolitics_classicial_french_critical/.

65. Trading Economics. (2019). Cameroon Exports. Retrieved August 15, 2019, from http://tradingeconomics.com/Cameroon/exports.

66. Unindependent Nations and Peoples Organization. (2018, March 26). Ambazonia: Nigeria Hands over47 Asylum-seekers to Cameroonian Authorities. Retrieved on July 30, 2019, from, http://unpo.org/article/201701.

67. UN Web TV. (2019, May 13). Arria-Formula Meeting of the UN Security Council. Retrieved September 18, 2019, from webtv.un.org/live-now/watch/arria-formula-meeting-of-the-unsecurity-council/6036271424001/?term=.

68. Voice of America. (2019, February 7). France to Continue Military Cooperation with Cameroon. Retrieved September 18, 2019, from https://www.voanews.com/europe/france-continuemilitary-cooperation-with-cameroon

69. Vollaard, H. (2007), 'Het Absorptievermogen van de EuropeseUnie', in H. Vollaard\& J. Penders (eds.), De Spankracht van de EuropeseUnie. Utrecht: Lemma. pp. 67-96. 
70. World Atlas. (2019). Where is the Gulf of Guinea? Retrieved August 20, 2019, from http://worldatlas.com/articles/where-is-thegulf-of-guinea.html.

71. World Bank. (2017). Cameroon exports, imports and trade balance by Country 2017. Retrieved September 15, 2019, from http://wits.worldbank.org/CountryProfile/en/Country/CMR/Year/ LTST/TradeFlow/EXPIMP/Partner/by-country.

72. World Population Review. (2019). World Population Review: Cameroon Population 2019. Retrieved August 15 2019, from worldpopulationreview.com/countries/cameroon-population/.

73. Young, J.B. (1987). Geography and Politics. The Royal Geographical Society/Institute of British Geographers. Vol 12, No 4. Pp. 391-397. 